\title{
Effect of Alnus nepalensis cultivation on soil biological and physicochemical properties during restoration near a phosphate smelter in Kunyang, Yunnan Province, SW China
}

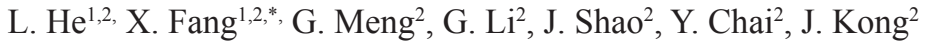 \\ ${ }^{1}$ College of Soil and Water Conservation, Beijing Forestry University, 100083, P. R. China ${ }^{2}$ Yunnan Academy of Forestry, \\ Kunming 650201, China *Corresponding authorE-mail: leiyb@xtbg.org.cn
}

\begin{abstract}
In this study, soil physicochemical properties, microbial community structure and nematode assemblages were investigated to assess the soil qualities of an in situ phosphate mine after up to 10 years of revegetation with the nurse plant Alnus nepalensis. Our results showed that A. nepalensis cultivation significantly decreased the total $\mathrm{P}$ concentration, suggesting the high remediation potential. Moreover, A. nepalensis improved the levels of soil-available $\mathrm{N}$ and $\mathrm{K}$ and promoted the growth of microorganisms, as suggested by the 1.45- and even 3.26fold increase in microbial carbon (MBC) and nitrogen (MBN), respectively, after 10 years of remediation. Soil enzyme activities relating to $\mathrm{C}$ ( $\beta$-glucosidase), $\mathrm{N}$ (urease) and $\mathrm{P}$ (acid phosphatase) were also stimulated. The sum of the indicator phospholipid fatty acids (PLFAs) and the Gram-positive and -negative bacteria also increased significantly after restoration. The nematode density increased gradually from zero in untreated soils to $2.3 \mathrm{~g}^{-1}$ of soil after 10 years of restoration, at which time the highest percentage of plant parasites was observed. Cluster analysis produced three clusters: cultivation for 0 and 1 years in cluster 1;2, 3 and 4 years in cluster 2; and 5 and 10 years in cluster 3 . These results showed that both the nutrient pools and the stability of the soil ecosystems in the revegetated soils were gradually reestablished and that the enzyme activities ( $\beta$-glucosidase and urease), the microbial community (sum of PLFAs, $\mathrm{G}^{+}: \mathrm{G}^{-}$) and the nematode assemblage (density and plant parasite percentage) might be used as valid bioindicators for soil heath after contamination remediation.
\end{abstract}

Keywords: Alnus nepalensis cultivation, microbial community structure, nematode assemblage, phospholipid fatty acids (PLFAs), soil enzyme activity 


\section{Introduction}

Decades of industrial growth worldwide have left an international legacy of soils polluted with a combination of toxic organic compounds and heavy metals. Heavy metal deposition may directly result in the loss of aboveground vegetation and the creation of large areas of industrial barrens (Helmisaari et al., 1995). The indirect effects of this pollution include not only the potential health risks of heavy metals to humans through food-chain and water contamination (Wong, 2003) but also the loss of the structure and function of the microbial communities that mediate soil processes, such as organic matter decomposition and nutrient and aggregate formation (Zhang et al., 2010). For these reasons, the enormous costs associated with the removal of soil pollutants using traditional physicochemical methods have stimulated the development of innovative biological technologies. Phytoremediation, or the use of green plants to remove pollutants from the environment or to render them harmless, is currently being considered as a promising, cost-effective and aesthetically pleasing technology for the remediation of polluted sites (Garbisu et al., 2002).

The successful restoration of disturbed environments requires careful consideration of all the components of the plant-soil system because many of the patterns observed aboveground are actually driven by belowground processes (Kelly et al., 2003). To date, however, the criteria for judging successful restoration have largely focused on aboveground indicators, whereas the soil ecosystem is often ignored during restoration. The ultimate goals of any remediation process should be not only to remove (or stabilize) the contaminants from the polluted site but also to restore the capacity of the soil to perform and function at its full potential (i.e., its health). Thus, relevant indicators are urgently needed to assess and monitor soil health (Schindlbacher et al., 2011).

Many studies have demonstrated increases in microbial community size and total heterotrophic activity in response to remediation, suggesting recovery of the microbial community (Kelly et al., 2003). However, measures of total microbial community size or activity focus on the community as a whole, and questions remain as to how metal contamination and remediation affect specific populations within soil microbial communities (Chowdhury et al., 2011). Changes in specific microbial populations are known to occur even when the total microbial community size remains unchanged (Renella et al., 2008), which suggests that measures of microbial community structure may allow for more sensitive assays than do measures of either general microbial processes or overall community size (Veresoglou et al., 2011). Thus, microbial community structure may be useful as a highly sensitive bioindicator of disturbance and remediation progress.

Previous work using isolation-based techniques has demonstrated that heavy metal contamination can cause shifts in microbial populations (Biederman and Whisenan, 2011). However, these techniques are limited in that they provide information on only a small component of the microbial community because few soil microbes can be cultured (Ward et al., 1990). Phospholipid fatty acid (PLFA) analysis can provide data indicative of microbial community structure. Changes in PLFA profiles can reflect changes in the overall structure of microbial communities, and "signature" PLFAs can provide information on specific groups of microorganisms present in a community. PLFA analysis offers an advantage over isolationbased techniques because it avoids the selectivity inherent in the isolation of microorganisms (Zhang et al., 2006). In addition, nematodes are an important component of the soil biota, with a considerable influence on organic matter decomposition and nutrient transformation (Londry and Sherriff, 2005). Nematodes are taxonomically diverse and represented on multiple trophic levels. Consequently, nematodes have been widely used as indicators of regeneration of the soil faunal community and as markers of ecosystem recovery after the remediation of polluted soils (Shao et al., 2008). 
The aim of the current work was to determine the influence of Alnus nepalensis cultivation for different periods on soil near a phosphate smelter. We hypothesized that nurse-plant cultivation changes the soil microbial community structure, enzyme activities and nematode assemblage and that these parameters can be used as valid monitoring tools to assess the efficacy of restoration processes following metal pollution.

\section{Materials and Methods}

\subsection{Site description and soil sample collection}

The revegetation sites were located at the Kunyang phosphate smelter, which is approximately $72 \mathrm{~km}$ from the city of Kunming in Yunnan province, SW China $\left(103^{\circ} 31^{\prime} 10^{\prime \prime}-103^{\circ} 34^{\prime} 48^{\prime \prime} \mathrm{E}\right.$ longitude, $24^{\circ} 12^{\prime} 58^{\prime \prime} \mathrm{N}$ latitude). This area has a subtropical monsoonal climate with a mean annual precipitation of 907 $\mathrm{mm}$, which mainly occurs from May to September. The average annual temperature is $14.7{ }^{\circ} \mathrm{C}$, with the average minimum and maximum temperature occurring in January $\left(-6{ }^{\circ} \mathrm{C}\right)$ and July $\left(30{ }^{\circ} \mathrm{C}\right)$, respectively. The phosphorus resource reserves were estimated at $1.02 \times 108 \mathrm{t}$ in this area, one of the largest basins of $\mathrm{P}$ mines in China (Zhang et al., 2010). Phosphate mining poses environmental challenges, including the production of large amounts of waste, mine drainage problems and heavy metal pollution, as suggested by the one ton each of waste sand and clay that is produced for each ton of final phosphate product (Krekeler et al., 2008). Clay-rich mine tailings from a half century of phosphate mining are a major environmental and economic problem resulting from reclamation and restoration difficulties.

The restoration program was launched in the 1990s, mainly through an Alnus nepalensis agroforestry system. A. nepalensis belongs to the family Betulaceae, and Alnus is the only genus in this family that can associate with Frankia to form nitrogen- fixing actinorhizal root nodules (Khan et al., 2007). A. nepalensis has a wide distribution at elevations of 1000-3000 $\mathrm{m}$ in the hilly regions of Yunnan Province, China. Because of its rapid growth, high wood quality and high nitrogen content in the leaves and branches, $A$. nepalensis is widely utilized as a pioneer plant for forest regeneration and the reclamation of nitrogen-depleted soils. For example, the people in Tengchong County, Yunnan Province, have a long history of planting crops, pines and A. nepalensis in rotation to improve the yield and soil fertility (Jiang, 2008). Our previous papers (Jiang, 2008; Zhang et al., 2010) investigated the following topics: the growth of A. nepalensis, the metal concentrations in different organs of A. nepalensis and its phytoextraction efficiency and a biodiversity field survey. The present study focused on the microbial and nematode community sampled belowground on 1 ha sites remediated for $0,1,2,3,4,5$ and 10 years. The soil samples were collected in October 2010. In each of the seven sampling sites, three bulk soil samples were collected with cutting rings $(64 \mathrm{~mm}$ in diameter and $100 \mathrm{~mm}$ in length). Each bulk sample consisting of ten subsamples was randomly collected at a depth of $0-20 \mathrm{~cm}$ and always taken more than $50 \mathrm{~cm}$ from the rhizosphere of individual plants. The field-moist soil samples were sieved $(<2 \mathrm{~mm})$ and immediately divided into two subsamples. In the laboratory, one soil subsample was stored at $4{ }^{\circ} \mathrm{C}$ for the determination of the microbial and nematode parameters. The other subsample was allowed to dry at room temperature for the analyses of physicochemical properties.

\subsection{Soil physicochemical analyses}

The soil $\mathrm{pH}$ was determined in $\mathrm{H}_{2} \mathrm{O}$ (soil: water $=$ 1:2) with a grass electrode using a Mettler-Toledo $\mathrm{pH}$ meter. The following soil parameters were determined: organic $\mathrm{C}$ using wet digestion according to the Turin method, total $\mathrm{N}$ by the Kjeldahl method, available $\mathrm{N}$ determined from the alkali hydrolyzable fraction, available $\mathrm{P}$ by the Olsen method and available $\mathrm{K}$ by inductively coupled plasma-atomic emission spectrometry (ICP-AES) after extraction with $1 \mathrm{M}$ ammonium acetate. All the above methods were 
conducted according to Yao (2006).

\subsection{Microbiological analyses}

The microbial biomass $\mathrm{C}$ (MBC) and $\mathrm{N}(\mathrm{MBN})$ were determined according to the $\mathrm{CHCl}_{3}$ fumigationextraction method. The carbon concentrations of the fumigated and non-fumigated samples were determined through oxidation with potassium dichromate, and the difference between the samples was divided by the recovery factor KEC (0.45). The nitrogen $(\mathrm{N})$ concentration was calculated as the difference between the $\mathrm{N}$ concentrations of the fumigated and non-fumigated samples determined through the colorimetric method, and the difference was divided by the recovery factor KEN (0.54) (Yao, 2006).

The nitrogen $(\mathrm{N})$ mineralization was determined by measuring the production of mineral $\mathrm{N}\left(\mathrm{NH}_{4}^{+}+\mathrm{NO}_{3}^{-}\right)$ during incubation (Bao, 2000). The incubations were conducted with $20 \mathrm{~g}$ (dry weight equivalent) of soil flooded with ultra-pure distilled water in an oven at $40{ }^{\circ} \mathrm{C}$ for 7 days. The soil was frozen until the soil mineral nitrogen was determined by analyzing the ammonium and nitrate N. For this determination, the samples were milled and homogenized in the frozen state. Subsamples of $15 \mathrm{~g}$ were extracted with 50 $\mathrm{mL}$ of $2 \mathrm{M} \mathrm{KCl}$, filtered and analyzed with a FIA Star-5000 continuous-flow analyzer. The amount of $\mathrm{N}$ mineralized was assessed by subtracting the preincubation $\mathrm{NH}_{4}^{+}$and $\mathrm{NO}_{3}^{-}$concentrations from the postincubation $\mathrm{NH}_{4}^{+}$and $\mathrm{NO}_{3}^{-}$concentrations. Then, the rate of net $\mathrm{N}$ mineralization for a given time period was calculated by dividing the net $\mathrm{N}$ mineralization by the number of days in the period. All the soil samples were analyzed at least in triplicate.

The soil activity of $\beta$-glucosidase was determined from the p-nitrophenol absorbance at $400 \mathrm{~nm}$ measured after the soil incubated with p-nitrophenyl glucoside. Urease activity was measured following the method of Yao (2006). A 7.5-mL aliquot of citrate buffer ( $\mathrm{pH} \mathrm{6.7)} \mathrm{and}$ $10 \mathrm{~mL}$ of $10 \%$ urea substrate solution were added to 10 $\mathrm{g}$ of soil, after which the samples were incubated for 3 $\mathrm{h}$ at $38^{\circ} \mathrm{C}$. Following filtration through filter paper, the filtrates were diluted, and the $\mathrm{NH}_{3}^{-} \mathrm{N}$ concentrations were determined colorimetrically at $578 \mathrm{~nm}$. Acid phosphatase activity was determined following the method of Lu (1999) using $\rho$-nitrophenylphosphate as the substrate and $0.1 \mathrm{~mol}^{-1}$ Tris at $\mathrm{pH} 5.5$ as the buffer. The sucrase, urease and acid phosphatase activities were expressed as $\mathrm{g}$ Suc, $\mathrm{g} \mathrm{NH}_{3}$ and $\mathrm{mg}$ PNFF kg${ }^{-1}$ of dry soil, respectively.

For the phospholipid fatty acid (PLFA) analysis, freeze-dried soil (4 g) was extracted with a onephase solvent of chloroform, methanol and citrate buffer $(1: 2: 0.8 \mathrm{v} / \mathrm{v} / \mathrm{v})$. The lipid-containing phase was collected and stored at $-20^{\circ} \mathrm{C}$ until it was dried under a stream of nitrogen at $40^{\circ} \mathrm{C}$. The PLFAs were separated from other fatty acids using silicic acid columns (Supelclean LCSi-SPE Tubes, Supelco). The columns were washed with chloroform, acetone and methanol, and the methanol fraction containing the PLFAs was collected. After alkaline methanolysis, the organic phase was collected in dichloromethane. An internal standard (methyl nonadecanoate, 19:0) was added to each sample.

The fatty acid methyl esters were separated in a gas chromatograph with a flame ionization detector (GC-FID) (HP 6890) using an SP-2560 fused-silica capillary column $(75 \mathrm{~m}, 180 \times 0.14 \mu \mathrm{m}$ film thickness, Supelco, Sigma-Aldrich, Australia) with helium as the carrier gas. The injector temperature was 250 ${ }^{\circ} \mathrm{C}$, and the detector temperature was $260{ }^{\circ} \mathrm{C}$. The temperature program was $140{ }^{\circ} \mathrm{C}$ initially, followed by a temperature increase of $4{ }^{\circ} \mathrm{C} / \mathrm{min}$ to $240{ }^{\circ} \mathrm{C}$, which was then held for $15 \mathrm{~min}$.

The individual PLFA peaks were identified by comparing their retention times with those of peaks produced by the Supelco 37 standard mixture (Supelco, Bellefonte, PA) and peaks identified by GC-MS (gas chromatograph combined with a mass selective detector, HP 5973) using the same column, temperature program and carrier gas as described above. During 
electron impact, the electron energy was $70 \mathrm{eV}$. The identification of the mass spectrometer peaks was based on comparisons with the software library NIST02.L. The amounts of individual PLFAs were expressed in $\mu \mathrm{g} \mathrm{g}^{-1}$ of soil. The following signature PLFAs were used as indicators for specific microorganism groups: 15:0 iso for gram-positive bacteria; 17:0 cyclo and 18:107c for Gram-negative bacteria; 17:0 10Me and

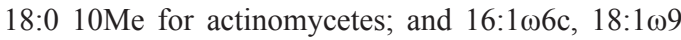

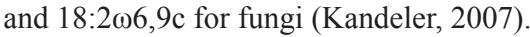

\subsection{Nematode extraction and analyses}

The nematodes were extracted over a $48 \mathrm{~h}$ period from $100 \mathrm{~g}$ (fresh weight) of each composite sample using a modified Baermann funnel technique (Barker, 1985). After fixation in 4\% formaldehyde solution, the nematodes were counted at $40 \times$ magnification to estimate their density. The extracted nematodes were mounted on mass slides, and the first 100 individuals encountered were identified to genus when possible. All the individuals were identified when fewer than 100 were present in a sample. The taxa were allocated to functional feeding types according to Yeates et al. (1993). These types were reduced to four groups: bacterivores, plant parasites, fungivores and omnivores.

\subsection{Statistical analyses}

The data were subjected to one-way analysis of variance (ANOVA) using the SPSS 11.5 for Windows statistical software package. The Fisher LSD test was employed to detect possible differences among the different remediation treatments. To classify the soil samples by integrated physiochemical and biological characteristics, those parameters that exhibited significant differences among the treatments, including the TOC, total $\mathrm{N}$, available $\mathrm{N}$, total $\mathrm{K}$, available $\mathrm{K}, \mathrm{MBC}, \mathrm{MBN}, \mathrm{N}$ mineralization and nematode density, were analyzed by cluster analysis (CA) using the K-means partitioning method. We carried out numerous classifications based on 10,000 iterations and employing the leave-one-out correction.
The connections between clusters issued in different partitions were established after comparing their intrinsic significance. The data-clustering algorithm was agglomerative (bottom-up) with distance optimization, and the squared Euclidean distance was used as the cluster distance among the different remediation durations.

\section{Results}

The soil physiochemical properties are summarized in Table 1. Soil $\mathrm{pH}$ increased considerably with the remediation time from 5.31 to 6.32 after 0 and 10 years of revegetation. Total $\mathrm{P}$ decreased gradually, and after 10 years of remediation, it was only $43.9 \%$ of that in the control, indicating the phytoremediation potential of A. nepalensis cultivation (Table 1). Revegetation also improved the soil nutrient status, including TOC, total and available $\mathrm{N}$ and $\mathrm{K}$, which were $3.03,2.98,5.45$, 1.99 and 2.13 times of the control value, respectively. For most of these parameters, remediation for 5 and 10 years produced higher values than did remediation for 0 to 4 years.

Microbial biomass increased significantly with the restoration process, as suggested by $\mathrm{MBC}$ and MBN, which cumulatively accounted for 9-14 and $3-6 \%$ of TOC and total N, respectively (Table 2). N mineralization rate and the three assessed enzyme activities increased significantly after revegetation. After restoration for 10 years, $\mathrm{N}$ mineralization, $\beta$-glucosidase, acid phosphatase and urease were 2.5 , 2.6, 1.3 and 2.7 times greater than the control values $(0$ year), respectively.

The sum of PLFAs increased considerably as the duration of the revegetation period increased, and the indicator PLFAs and their ratios signifying different functional groups also changed profoundly (Table 3 and Figure 1). The 16:1 $155 \mathrm{c}$ PLFA, which is an indicator of arbuscular mycorrhizal fungi, increased gradually after

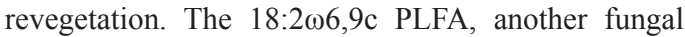


indicator, also increased significantly with longer remediation time. Additionally, a significant increase was observed in actinomycetes, as indicated by the increases in the 17:0 10 Me and 18:0 10Me PLFAs. As the restoration time lengthened, the Gram-negative bacteria decreased, as indicated by the lower levels of the $18: 1 \omega 7 \mathrm{c}$ and 17:0 cyclo PLFAs, whereas the Grampositive bacteria increased, as indicated by the higher levels of 15:0 iso, resulting in a significantly higher ratio of $\mathrm{G}^{+}$: $\mathrm{G}^{-}$. The ratio of fungi: bacteria was higher with the remediation treatment but did not differ with the duration of remediation.

There was considerable variation in the nematode density, which increased gradually from zero in the untreated soil samples to $2.3 \mathrm{~g} \mathrm{~g}^{-1}$ of soil after 10-year remediation (Figure 2).
Relative abundance of the four trophic groups also changed significantly with the duration of remediation, especially the increase in the percentage of plant parasites. The longest remediation period (10 years) exhibited the highest percentages of fungivores and plant parasites. There was no consistent change in the relative abundance of the bacterivores and omnivores during the course of the remediation.

The cluster analysis (CA) showed that a three-group clustering best describes the different remediation histories (Figure 3 ). The dendrogram clearly shows remediation years 0 and 1 grouped in cluster 1 ; years 2, 3 and 4 in cluster 2; and years 5 and 10 (i.e., the longest restorations examined) composing cluster 3

Table 1. Changes in soil physiochemical properties after 0 to 10 years of restoration

\begin{tabular}{llllllll}
\hline Year & $\mathrm{pH}$ & $\begin{array}{l}\text { Total } \mathrm{P} \\
\left(\mathrm{g} \mathrm{kg}^{-1}\right)\end{array}$ & $\begin{array}{l}\text { Total organic } \\
\text { carbon }\left(\mathrm{g} \mathrm{kg}^{-1}\right)\end{array}$ & $\begin{array}{l}\text { Total } \mathrm{N} \\
\left(\mathrm{g} \mathrm{kg}^{-1}\right)\end{array}$ & $\begin{array}{l}\text { Available N } \\
\left(\mathrm{mg} \mathrm{kg}^{-1}\right)\end{array}$ & $\begin{array}{l}\text { Total K } \\
\left(\mathrm{g} \mathrm{kg}^{-1}\right)\end{array}$ & $\begin{array}{l}\text { Available K } \\
\left(\mathrm{mg} \mathrm{kg}^{-1}\right)\end{array}$ \\
\hline 0 & $5.31 \pm 0.61 \mathrm{~b}$ & $4.12 \pm 0.51 \mathrm{a}$ & $2.51 \pm 0.91 \mathrm{c}$ & $0.51 \pm 0.07 \mathrm{c}$ & $20.3 \pm 5.51 \mathrm{c}$ & $13.7 \pm 2.1 \mathrm{~d}$ & $117.7 \pm 19.5 \mathrm{c}$ \\
1 & $5.23 \pm 0.41 \mathrm{~b}$ & $4.21 \pm 0.92 \mathrm{a}$ & $2.63 \pm 0.64 \mathrm{c}$ & $0.71 \pm 0.17 \mathrm{~b}$ & $24.0 \pm 6.62 \mathrm{c}$ & $16.8 \pm 2.3 \mathrm{~cd}$ & $135.0 \pm 15.5 \mathrm{bc}$ \\
2 & $5.51 \pm 0.42 \mathrm{~b}$ & $3.05 \pm 0.67 \mathrm{~b}$ & $4.41 \pm 1.46 \mathrm{bc}$ & $0.81 \pm 0.26 \mathrm{~b}$ & $23.0 \pm 5.02 \mathrm{c}$ & $19.3 \pm 3.2 \mathrm{bc}$ & $151.3 \pm 18.2 \mathrm{bc}$ \\
3 & $5.43 \pm 0.31 \mathrm{~b}$ & $3.24 \pm 0.72 \mathrm{~b}$ & $5.32 \pm 1.03 \mathrm{~b}$ & $0.91 \pm 0.19 \mathrm{~b}$ & $25.0 \pm 7.95 \mathrm{c}$ & $20.5 \pm 2.5 \mathrm{bc}$ & $157.7 \pm 31.3 \mathrm{bc}$ \\
4 & $5.32 \pm 0.53 \mathrm{~b}$ & $3.11 \pm 0.53 \mathrm{~b}$ & $5.41 \pm 0.45 \mathrm{~b}$ & $0.81 \pm 0.13 \mathrm{~b}$ & $43.0 \pm 12.5 \mathrm{~b}$ & $21.4 \pm 2.6 \mathrm{bc}$ & $177.0 \pm 46.5 \mathrm{~b}$ \\
5 & $6.02 \pm 0.31 \mathrm{ab}$ & $2.02 \pm 0.33 \mathrm{c}$ & $7.52 \pm 1.73 \mathrm{a}$ & $1.41 \pm 0.30 \mathrm{a}$ & $107.3 \pm 11.9 \mathrm{a}$ & $24.3 \pm 3.4 \mathrm{ab}$ & $214.3 \pm 29.1 \mathrm{ab}$ \\
10 & $6.32 \pm 0.53 \mathrm{a}$ & $1.81 \pm 0.52 \mathrm{c}$ & $7.60 \pm 2.11 \mathrm{a}$ & $1.52 \pm 0.12 \mathrm{a}$ & $110.7 \pm 6.1 \mathrm{a}$ & $27.3 \pm 3.9 \mathrm{a}$ & $249.3 \pm 26.0 \mathrm{a}$ \\
\hline
\end{tabular}

Values (mean $\pm \mathrm{SE}, \mathrm{n}=3$ ) within columns followed by different letters differ significantly at $p<0.05$. 
Table 2. Changes in soil microbial biomass and enzyme activities after 0 to 10 years of restoration

\begin{tabular}{|c|c|c|c|c|c|c|}
\hline \multirow{2}{*}{$\begin{array}{l}\text { Year } \\
\\
0\end{array}$} & \multirow{2}{*}{$\begin{array}{l}\mathrm{MBC} \\
\left(\mathrm{mg} \mathrm{kg}^{-1}\right) \\
350.3 \pm 35.8 \mathrm{~d}\end{array}$} & \multirow{2}{*}{$\begin{array}{l}\text { MBN } \\
\left(\mathrm{mg} \mathrm{kg}^{-1}\right) \\
12.6 \pm 2.6 \mathrm{c}\end{array}$} & \multicolumn{2}{|c|}{$\begin{array}{l}\mathrm{N} \text { mineralization } \beta \text {-glucosidase } \\
\text { rate }\left(\mathrm{mg} \mathrm{kg}^{-1} \mathrm{~d}^{-1}\right)\left(\mathrm{g} \mathrm{PNP} \mathrm{kg}^{-1} \text { dry soil) }\right.\end{array}$} & \multicolumn{2}{|c|}{$\begin{array}{l}\text { Acid phosphatase Urease } \\
\text { (g PNFF kg }{ }^{-1} \text { dry soil) }\left(\mathrm{g} \mathrm{NH}_{3} \mathrm{~kg}^{-1} \text { dry soil) }\right.\end{array}$} \\
\hline & & & $10.3 \pm 2.1 \mathrm{c}$ & $2.13 \pm 0.31 \mathrm{c}$ & $22.8 \pm 5.5 \mathrm{~b}$ & $.10 \pm 0.03 \mathrm{~b}$ \\
\hline 1 & $503.0 \pm 21.1 \mathrm{c}$ & $14.3 \pm 3.4 \mathrm{c}$ & $13.3 \pm 3.1 \mathrm{bc}$ & $2.30 \pm 0.52 \mathrm{c}$ & $22.7 \pm 3.5 \mathrm{~b}$ & $.12 \pm 0.03 \mathrm{~b}$ \\
\hline 2 & $558.7 \pm 30.3 \mathrm{c}$ & $35.3 \pm 9.8 \mathrm{~b}$ & $15.1 \pm 2.8 \mathrm{bc}$ & $3.01 \pm 0.36 \mathrm{bc}$ & $22.5 \pm 2.6 \mathrm{~b}$ & $0.15 \pm 0.05 \mathrm{ab}$ \\
\hline 3 & $723.7 \pm 43.5 \mathrm{~b}$ & $41.9 \pm 8.1 \mathrm{ab}$ & $15.5 \pm 2.5 \mathrm{bc}$ & $3.77 \pm 0.65 \mathrm{~b}$ & $30.3 \pm 5.3 \mathrm{ab}$ & $0.18 \pm 0.03 \mathrm{ab}$ \\
\hline 4 & $718.3 \pm 16.2 \mathrm{~b}$ & $42.3 \pm 7.9 \mathrm{ab}$ & $17.5 \pm 1.9 \mathrm{~b}$ & $3.30 \pm 0.76 \mathrm{bc}$ & $31.9 \pm 4.9 \mathrm{a}$ & $.18 \pm 0.04 \mathrm{ab}$ \\
\hline 5 & $845.7 \pm 37.2$ a & $50.9 \pm 2.4$ a & $23.5 \pm 4.6 \mathrm{a}$ & $5.13 \pm 0.96 \mathrm{a}$ & $29.4 \pm 4.4 \mathrm{ab}$ & $.20 \pm 0.05 a b$ \\
\hline 10 & $857.0 \pm 35.0 \mathrm{a}$ & $53.7 \pm 4.7 \mathrm{a}$ & $25.5 \pm 5.5 \mathrm{a}$ & $5.63 \pm 0.91 \mathrm{a}$ & $30.6 \pm 4.5 \mathrm{a}$ & $.27 \pm 0.06 \mathrm{a}$ \\
\hline
\end{tabular}

Values (mean $\pm \mathrm{SE}, n=3$ ) within columns followed by different letters differ significantly at $p<0.05 \mathrm{MBC}$ is microbial carbon; $\mathrm{MBN}$ is microbial nitrogen.

Table 3. Changes in indicator phospholipid fatty acids of soils after 0 to 10 years of restoration

\begin{tabular}{|c|c|c|c|c|c|c|c|c|}
\hline & $16: 1 \omega 5 c$ & $18: 1 \omega 9 c$ & $18: 2 \omega 6,9 c$ & 17:0 10Me & $18: 010 \mathrm{Me}$ & $15: 0$ iso & $18: 1 \omega 7 \mathrm{c} \quad 1$ & 17:0 cyclo \\
\hline 0 & $1.23 \pm 0.23 \mathrm{de}$ & $5.40 \pm 1.6 \mathrm{c}$ & $1.37 \pm 0.57 \mathrm{c}$ & $0.57 \pm 0.20 \mathrm{~b}$ & $1.12 \pm 0.41 \mathrm{~b}$ & $2.65 \pm 0.62 \mathrm{~d}$ & $5.25 \pm 1.16 \mathrm{a}$ & $1.53 \pm 0.57 \mathrm{a}$ \\
\hline 1 & $1.90 \pm 0.34 \mathrm{~d}$ & $8.16 \pm 3.5 \mathrm{a}$ & $1.77 \pm 0.63 c$ & $0.66 \pm 0.21 \mathrm{~b}$ & $1.03 \pm 0.37 \mathrm{~b}$ & $2.49 \pm 0.75 \mathrm{~d}$ & $4.59 \pm 0.55 \mathrm{ab}$ & b $\quad 1.50 \pm 0.44 \mathrm{a}$ \\
\hline 2 & $2.34 \pm 0.33 c$ & $6.73 \pm 1.7 \mathrm{~b}$ & $1.95 \pm 0.58 \mathrm{c}$ & $0.71 \pm 0.21 \mathrm{~b}$ & $1.41 \pm 0.64 \mathrm{ab}$ & $3.00 \pm 0.68 \mathrm{c}$ & $3.92 \pm 0.35 b$ & $1.32 \pm 0.23 a$ \\
\hline 3 & $1.73 \pm 0.53 \mathrm{~d}$ & $5.52 \pm 2.3 c$ & $2.30 \pm 0.43 \mathrm{a}$ & $1.22 \pm 0.27 \mathrm{ab}$ & $2.37 \pm 0.27 \mathrm{a}$ & $3.16 \pm 0.67 \mathrm{c}$ & $3.34 \pm 0.51 b$ & $1.47 \pm 0.35 \mathrm{a}$ \\
\hline 4 & $2.59 \pm 0.45 c$ & $6.41 \pm 1.2 \mathrm{c}$ & $2.57 \pm 0.35 \mathrm{a}$ & $1.23 \pm 0.22 \mathrm{ab}$ & $2.21 \pm 0.61 \mathrm{a}$ & $4.06 \pm 0.61 \mathrm{~b}$ & $2.99 \pm 0.42 b$ & $1.26 \pm 0.26 \mathrm{a}$ \\
\hline 5 & $3.90 \pm 0.22 \mathrm{~b}$ & $4.41 \pm 1.0 \mathrm{~d}$ & $3.31 \pm 0.50 \mathrm{ab}$ & $1.37 \pm 0.27 \mathrm{ab}$ & $2.35 \pm 0.22 \mathrm{a}$ & $4.69 \pm 0.40 \mathrm{ab}$ & $3.17 \pm 0.34 \mathrm{~b}$ & $1.25 \pm 0.26 a$ \\
\hline 10 & $4.57 \pm 0.53 \mathrm{a}$ & $3.94 \pm 0.7 \mathrm{~d}$ & $4.16 \pm 0.52 \mathrm{a}$ & $1.55 \pm 0.13 \mathrm{a}$ & $2.84 \pm 0.51 \mathrm{a}$ & $5.44 \pm 0.83 a$ & $3.31 \pm 0.54 \mathrm{~b}$ & $1.29 \pm 0.61 \mathrm{a}$ \\
\hline
\end{tabular}

Values (mean $\pm \mathrm{SE}, n=3$ ) within columns followed by different letters differ significantly at $p<0.05$. 

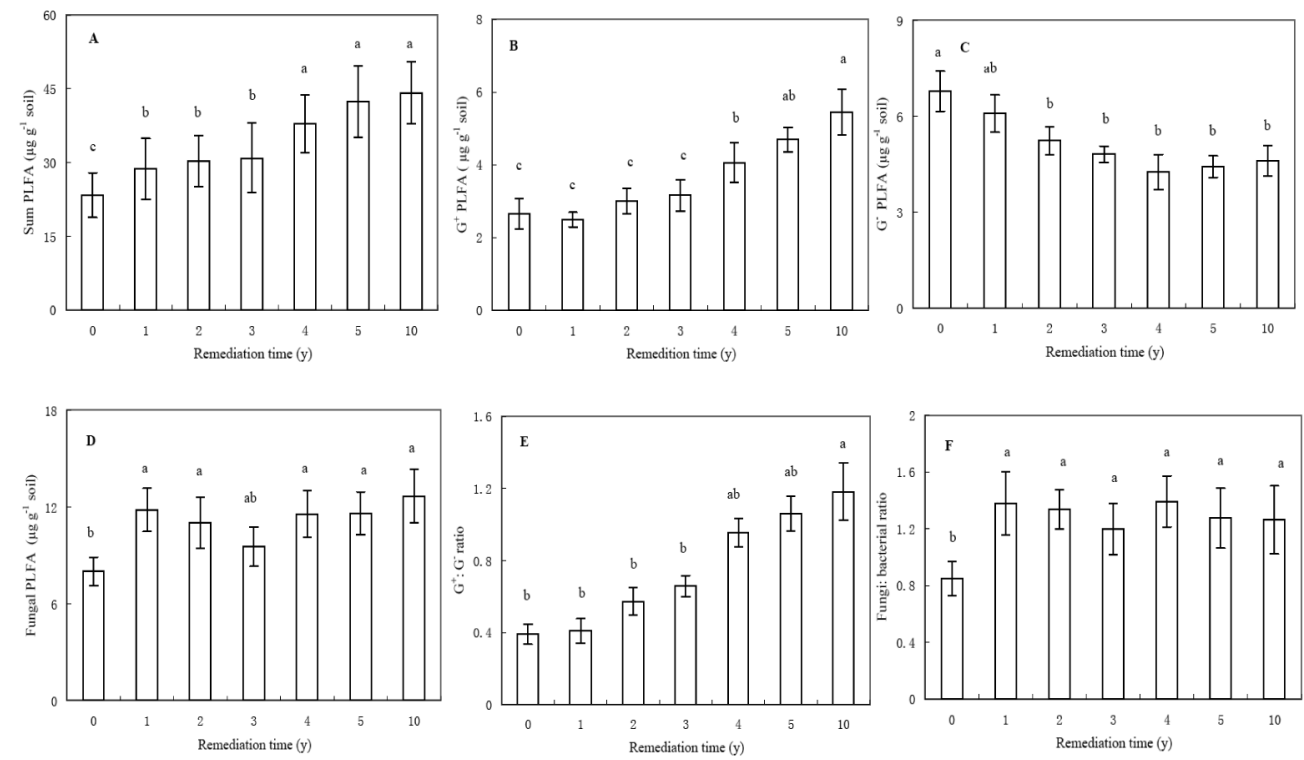

Figure 1. Changes in microbial community structure suggested by phospholipid fatty acids (PLFAs) of soils at different restoration durations

A, PLFA sum; B, G ${ }^{+}$PLFA; C, G- PLFA; D, fungal PLFA; E, G': G- ratio; and F, fungi: bacterial ratio. Values (mean $\pm \mathrm{SE}, n=3$ ) with different letters above the bars differ significantly at $p<0.05$.

\section{Discussion}

It is generally accepted that heavy metal contamination results not only in adverse effects on various plant growth parameters but also in changes to the size, composition and activity of the soil microbial community (Giller et al., 1998). Soil microorganisms play a crucial role in increasing soil fertility and accelerating the revegetation process through their activities in disturbed soils (Renella et al., 2008). In the present study, the remediation through agroforestry systems (i.e., an Alnus nepalensis plantation) improved the soil chemical properties; for example, the total $\mathrm{P}$ concentration was decreased by $43 \%$ to $1.81 \mathrm{~g} \mathrm{~kg}^{-1}$ after ten years of $A$. nepalensis cultivation. The total $\mathrm{P}$ exceeded 4 $\mathrm{g} \mathrm{kg}^{-1}$ in the control lacking remediation, which is significantly higher than optimal for normal plant growth (0.4-1.5 $\mathrm{g} \mathrm{kg}^{-1}$ ) (Yao, 2006). Moreover, the A. nepalensis plantation helped to increase soil $\mathrm{pH}$, and significantly improve soil nutrient levels (organic $\mathrm{C}$ and total and available $\mathrm{N}$ and $\mathrm{K}$ ) and promote the growth and activity of multiple microbial groups (Kelly et al., 2003). Thus, revegetation with Alnus nepalensis appears to beneficially affect soil biological activity and, concomitantly, soil heath (Table 1).

The stimulatory effect from revegetation might be due to the presence of extra $\mathrm{C}$ from plant litter 
and root exudates. Indeed, compared to bare soil, vegetated soils are frequently reported to have both higher microbial biomass and higher rates of microbial activity because of the presence of additional surfaces for microbial colonization and organic compounds released by the plant roots and litter (Moynahan et al., 2002). The soil microbial biomass, which serves as a pool of nutrients and plays an important role in ecosystem sustainability, is a sensitive indicator of microbial changes in soil polluted by increased heavy metal concentrations (Vig et al., 2003) and is widely used to evaluate soil quality. Soil enzymes are often used to estimate the adverse effects of various pollutants on soil quality (Hashimoto et al., 2009). $\beta$-Glucosidase is the ratelimiting enzyme in the microbial degradation of cellulose to glucose and plays a crucial role in the soil C cycle. Moynahan et al. (2002) found $\beta$-glucosidase activity to be significantly and positively correlated with the organic $\mathrm{C}$ content, which was confirmed by our study, in which it appeared that the organic $\mathrm{C}$ input was the major cause of the improved $\beta$-glucosidase activity levels. In our study, the acid phosphatase activity remained high throughout the 10 years of remediation (Table 2). Urease and its substrate are key components in the soil nitrogen cycle, and urease increased to 2.7 times the control value after 10 years of revegetation, which is consistent with the increases observed for the total and available $\mathrm{N}$ (Tables 1 and 2). The lower enzyme activities in soils without remediation may be due to energy diversion into physiological adaptations necessary to tolerate the heavy metals, such as the synthesis of intraand extracellular metal-sequestering proteins or saccharides, and biochemical reactions to precipitate or trap the metals onto microbial surfaces (Renella et al., 2008).

The PLFA profiles indicated that the remediated soils contained greater levels of indicator PLFAs for fungi, actinomycetes and Gram-positive bacteria than did the unremediated metal-contaminated soil; the presence of these organisms in microbial communities is usually beneficial for plant growth. Our results indicate that the sum of the PLFAs and the $\mathrm{G}^{+}$: $\mathrm{G}^{-}$ratio are two reliable microbial indictors for soil health assessment (Figure 1). Nematodes are an important component of the soil biota because of their considerable influence on organic matter decomposition and nutrient transformation. They are taxonomically diverse and are represented in multiple trophic levels. Consequently, nematodes have been widely used as indicators of the regeneration of the soil faunal community and ecosystem remediation (Shao et al., 2008). In our study, the nematode density increased gradually from zero in the untreated soils to $2.3 \mathrm{~g} \mathrm{~g}^{-1}$ of soil after 10 years of restoration, when the plant parasites reached their highest relative abundance, which indicates that these two parameters might be valid markers of recovery (Figure 2). Similarly, Courtney et al. (2011) studied nematode assemblage responses to bauxite residue remediation for different durations after the addition of compost or gypsum and found that the nematode density, the taxa richness and the maturity index were improved after revegetation.

Cluster analysis was used to evaluate how soil physicochemical, microbial and nematode parameters characterized the progressive soil regeneration at different durations after revegetation. The analysis suggested that the short remediations $(0,1$ and 2 years) were clustered in one group and the intermediate durations in a second, closely related group. The long-duration (5 and 10 years) restorations were clustered in a third, more distantly related group (Figure 3). Similarly, Kelly et al. (2003) observed that more recently remediated sites had PLFA profiles most like heavily Zn-contaminated sites and that the sites that had been remediated earlier (10 years) had PLFA profiles more like the least contaminated sites. In conclusion, our results showed that both the nutrient pools and the stability of the soil ecosystems in the revegetated soils were gradually reestablished and that the enzyme activities, microbial community and nematode assemblage might be used as valid bioindicators of soil heath during remediation after heavy metal contamination. 

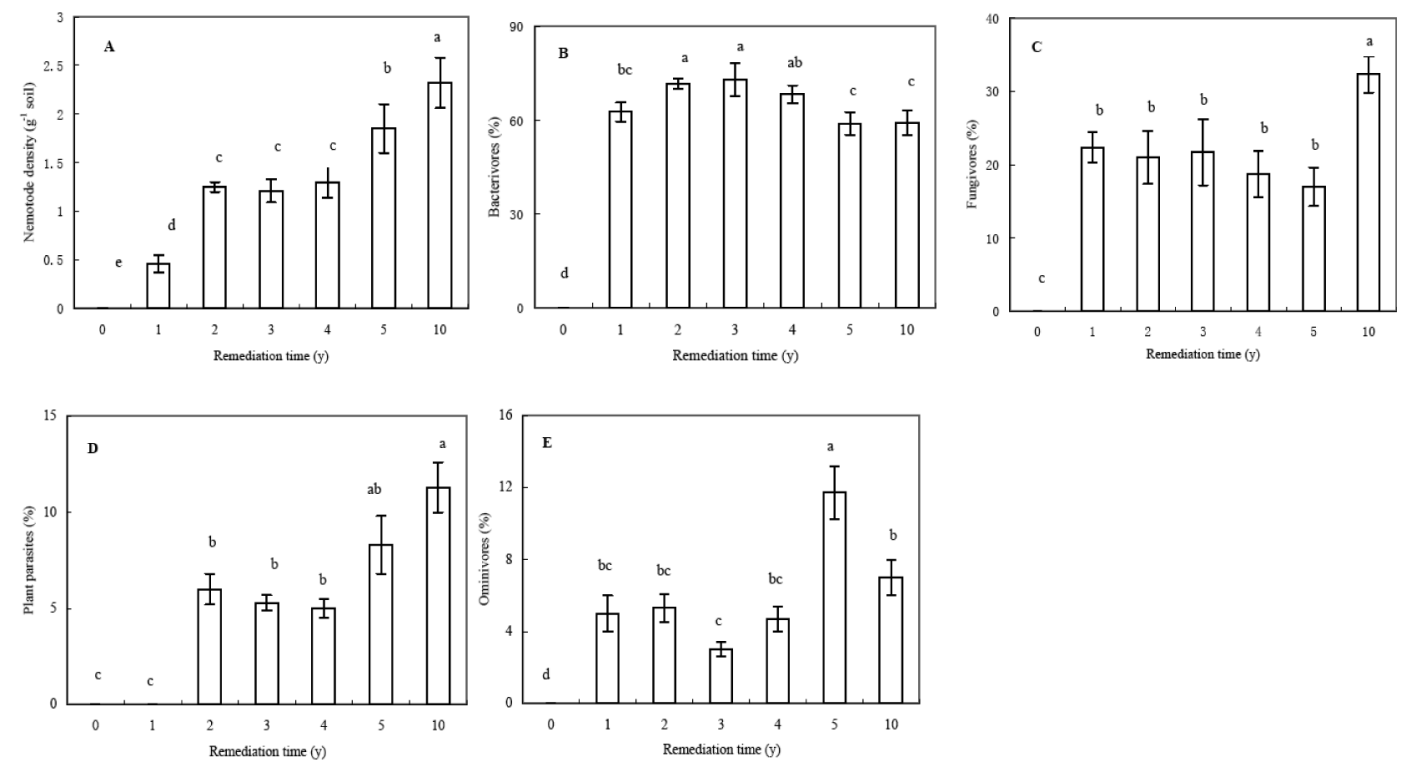

Figure 2. Changes in nematode assemblage of soils at different restoration durations

Values (mean $\pm \mathrm{SE}, n=3$ ) with different letters above the bars differ significantly at $p<0.05$.

A, nematode density; $\mathrm{B}$, bacterivore percentage; $\mathrm{C}$, fungivores percentage; $\mathrm{D}$, plant parasites percentage; and $\mathrm{E}$, ominivores percentage.

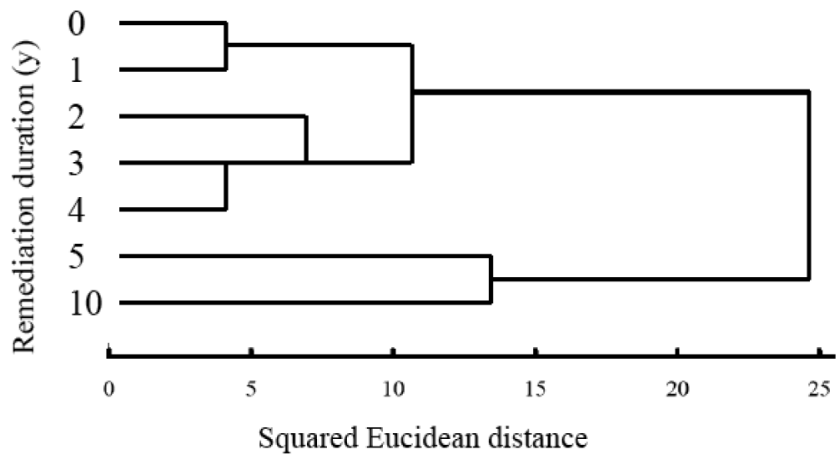

Figure 3. Cluster dendrogram of soil heath parameters at different remediation durations 


\section{Acknowledgements}

The authors are grateful to Yunnan Phosphate Chemical Group Co., Ltd. for logistic support. This study was funded by the R\&D Special Fund for Forestry Public Welfare Industry "Key revegetation technology research on woodland damaged by construction" (200904030). We would also like to thank Christine Verhille at the University of British Columbia and American Journal Experts for their assistance with English language and grammatical editing of the manuscript.

\section{References}

Bao, S.D. 2000. Methods for Soil Agricultural Chemical Analysis. Chinese Agricultural Press, Beijing, pp. 30-375

Barker, K.R. 1985. Nematode extraction and bioassays. In: Barker, K.R., Carter, C.C., Sasser, J.N. (eds). An advanced treatise on meloidogyne, methodology. Vol. 2. State University Graphics, Raleigh, North Carolina, pp. 19-35

Biederman, L.A., Whisenant, S.G. 2011. Amendment placement directs soil carbon and nitrogen cycling in severely disturbed soils. Restor. Ecol. 19, 360-370.

Chowdhury, N., Marschner, P., Burns, R. 2011. Response of microbial activity and community structure to decreasing soil osmotic and matric potential. Plant Soil. 344, 241-254.

Courtney, R., Keith, A.M., Harrington, T. 2011. Nematode assemblages in bauxite residue with different restoration histories. Restor. Ecol. 19, 758764.

Courtney, R., Keith, A.M., Harrington, T. 2011. Nematode assemblages in bauxite residue with different restoration histories. Restor. Ecol. 19, 758-764.

Garbisu, C., Hernandez-Allica, J., Barrutia, O.,
Alkorta, I., Becerril, J.M. 2002. Phytoremediation: a technology using green plants to remove contaminants from polluted areas. Rev. Environ. Health. 17, 75-90.

Giller, K.E., Witter, E., McGrath, S.P. 1998. Toxicity of heavy metals to microorganisms and microbial processes in agricultural soil: a review. Soil Biol. Biochem. 130, 1389-1414.

Hashimoto, Y., Matsufuru, H., Takaoka, M., Tanida, H., Sato, T. 2009. Impacts of chemical amendment and plant growth on $\mathrm{Pb}$ speciation and enzyme activities in a shooting range soil: an X-ray absorption fine structure (XAFS) investigation. J. Environ. Qual. 38, 1420-1428.

Helmisaari, H.S., Derome, J., Fritze, H., Nieminen, T., Palmgren, K., Salemaa, M., Vanha-Majamaa, I. 1995. Copper in Scots pine forests around a heavymetal smelter in south-western Finland. Water Air Soil Pollut. 85, 1727-1732.

Jiang, P.X. 2008. Study on the vegetation after remediation of Kunyang phosphate smelter. Master degree dissertation. Kunming University of Science and Technology

Kandeler, E. 2007. Physiological and biochemical methods for studying soil biota and their function. In: Paul, E.A. (ed) Soil microbiology, ecology, and biochemistry. Elsevier, pp. 53-84

Kelly, J.J., Haggblom, M.M., Tate, R.L. 2003. Effects of heavy metal contamination and remediation on soil microbial communities in the vicinity of a zinc smelter as indicated by analysis of microbial community phospholipid fatty acid profiles. Biol. Fert. Soils. 38, 65-71.

Khan, A., Myrold, D.D., Misra, A.K. 2007. Distribution of Frankia genotypes occupying Alnus nepalensis nodules with respect to altitude and soil characteristics in the Sikkim Himalayas. Physiol. Plant. 130, 364-371. 
Krekeler, M.P.S., Morton, J., Lepp, J., Tselepis, C.M., Samsonov, M., Kearns, L.E. 2008. Mineralogical and geochemical investigation of clay-rich mine tailings from a closed phosphate mine, Bartow Florida, USA. Environ. Geol. 55, 123-147.

Liao, M., Xie, X.M., Ma, A.L., Peng, Y. 2010. Different influences of cadmium on soil microbial activity and structure with Chinese cabbage cultivated and non-cultivated. J. Soils Sediments. 10, 818-826.

Londry, K.L., Sherriff, B.L. 2005. Comparison of microbial biomass, biodiversity, and biogeochemistry in three contrasting gold mine tailings deposits. Geomicrobiology J. 22, 237-247.

Lu, R.K. 1999. Methods for Soil Agricultural Chemical Analysis. Agriculture, Science and Technology Press of China, pp. 239-241.

Moynahan, O.S., Zabinski, C., Gannon, J.E. 2002. Microbial community structure and carbonutilization diversity in a mine tailings Revegetation study. Restor. Ecol. 10, 77-87.

Renella, G., Landi, L., Ascher, J., Ceccherini, M.T., Pietramellara, G., Mench, M., Nannipieri, P. 2008. Long-term effects of aided phytostabilisation of trace elements on microbial biomass and activity, enzyme activities, and composition of microbial community in the Jales contaminated mine spoils. Environ. Pollution. 152, 702-712.

Schindlbacher, A., Rodler, A., Kuffner, M., Kitzler, B., Sessitsch, A., Zechmeister-Boltensten, S. 2011. Experimental warming effects on the microbial community of a temperate mountain forest soil. Soil Biol. Biochem. 43, 1417-1425.

Shao, Y., Zhang, W., Shen, J., Zhou, L., Xia, H., Shu, W., Ferris, H., Fu, S. 2008. Nematodes as indicators of soil recovery in tailings of a lead/zinc mine. Soil Biol. Biochem. 40, 2040-2046.

Sukul, P. 2006. Enzymatic activities and microbial biomass in soil as influenced by metalaxyl residues. Soil Biol. Biochem. 38, 320-326.

Veresoglou, S.D., Mamolos, A.P., Thornton, B., Voulgari, O.K., Sen, R., Vereogou, D.S. 2011. Medium-term fertilization of grassland plant communities masks plant species-linked effects on soil microbial community structure. Plant Soil. 344, 187-196.

Vig, K., Megharaj, M., Sethunathan, N., Naidu, R. 2003. Bioavailability and toxicity of lead to microorganisms and their activities in soil: a review. Adv. Environ. Res. 8, 121-135.

Ward, D.M., Wellerm, R., Bateson, M.M. 1990. 16srRNA sequences reveal numerous uncultured microorganisms in a natural community. Nature. $345,63-65$

Wong, M.H. 2003. Ecological restoration of mine degraded soils, with emphasis on metal contaminated soils. Chemosphere. 50, 775-780.

Yao, K.Y. 2006. Determination of soil microbial activities and character. In: Yao, K.Y., \& Huang, C.Y. (Eds.), Soil Microbial Ecology and Experimental Technology. Science Press, pp. 24-191.

Yeates, G.W., Bongers, T., De Goede, R.G., Freckman, D., Georgieva, S.S. 1993. Feeding habits in soil nematode families and genera: an outline for soil ecologists. J. Nematology. 25, 315-331.

Zhang, C.B., Huang, L.N., Wong, M.H., Zhang, J.T., Zhai, C.J., Lan, C.Y. 2006. Characterization of soil physicochemical and microbial parameters after revegetation near Shaoguan $\mathrm{Pb} / \mathrm{Zn}$ smelter, Guangdong, P.R. China. Water Air Soil Pollut. 177, 81-101.

Zhang, Z.Y., Tang, Y.A., Fang, X.J. 2010. Study on correlation of mining wasteland soil and encomia heavy metal pollution. Journal of Anhui Agricultural Science, 38, 8097-8098 